\title{
Application of Co-Production in Waste Management Through Waste Banks Program in Batu City
}

\author{
Sulung Satriyo Irkham P, Saiman, Muhammad Kamil \\ Email : sulungirham@gmail.com, saiman@umm.ac.id, kamil@umm.ac.id \\ University of Muhammadiyah Malang
}

\section{Article Info :}

\section{Article history :}

Received : August 2, 2019

Revised : September 11, 2019

Accepted : October 9, 2019

ISSN 2620-8091, Online 2620-3812

\section{ABSTRACT}

The Environment Agency holds the Waste Management System Program (DLH) Batu City seems to be unable to access waste problems in the upstream sector, particularly household waste from residential settlements. This lack capacity of the program followed up by DLH by organizing a waste bank program through the establishment of the Community Waste Bank (KBS) Kartini Sejati, which coordinated around 60 waste banks in Batu City to be involved in waste management. This study aims to explain the involvement of KBS Kartini Sejati in waste management in co-production and the obstacles faced by it. The concept of co-production refers to an alternative theory in the implementation of public services where application focuses on the dominant role of the community, while the government or other parties such as the private sector are only facilitators. This research uses the qualitative method by utilizing data from observations, interviews, and documentation. The results of this study indicate that KBS Kartini Sejati in several of its activities which include training in waste management, waste management, and "Sapu Bersih Sanpah Nyemplung Kali" (Saberpungli) have applied the principles of co-production. It is due to those activities that have implemented six co-production principles, namely the development of community capacity, mutually beneficial relationships between actors, network development, the government as a facilitator and catalyst, and the community as an essential asset in implementing services. The problems this program is the limitations of the budgetary resources, the decreasing level of public awareness to be active in waste banks, and the lack of innovation in waste management.

Keywords: batu city; co-production; waste bank; waste management

\section{ABSTRAK}

Program Sistem Pengelolaan Sampah yang dimiliki oleh Dinas Lingkungan Hidup (DLH) Kota Batu nampaknya kurang mampu mengakses permasalahan sampah di sektor hulu yakni sampah rumah tangga dari permukiman penduduk. Keterbatasan kapasitas dari program tersebut ditindak lanjuti oleh DLH dengan menyelenggarakan

Please cite this article as : Sulung Satrio I.P et al., Application of Co-Production In Waste Management Through Waste

Banks Program In Batu City : Journal of Local Government Issues (LOGOS), 
program bank sampah melalui pendirian Komunitas Bank Sampah (KBS) Kartini Sejati yang mengkoordinir sekitar 60 bank sampah di Kota Batu untuk terlibat dalam pengelolaan sampah. Penelitian ini bertujuan untuk menjelaskan keterlibatan KBS Kartini Sejati dalam pengelolaan sampah dalam perpekstif co-production dan kendala-kendala yang di hadapinya. Konsep co-production merupakan konsep alternatif dalam penyelenggaraan pelayanan publik dimana pelaksanannya menitikberatkan peran dominan dari masyarakat, sedangkan pemerintah atau pihak lainnya seperti swasta hanya sebagai fasilitator. Penelitian ini menggunakan metode kualitatif dengan memanfaatkan data hasil observasi, wawancara dan dokumentasi. Hasil penelitian ini menunjukkan bahwa KBS Kartini Sejati dalam beberapa kegiatannya yang meliputi kegiatan pelatihan pengelolaan sampah, pengelolaan sampah, dan "Sapu Bersih Sampah Nyemplung Kali" (Saberpungli) telah menerapkan prinsip-prinsip co-production..Kendala program ini adalah keterbatasan sumbder daya anggaran, menurunnya tingkat kesadaran masyarakat untuk aktif dalam bank sampah, dan minimnya inovasi dalam pengelolaan sampah.

Kata kunci: bank sampah; co-production; kota batu; pengelolaan sampah

\section{INTRODUCTION}

Environmental problems are a complexity which has received significant attention in this current world. One of the most complex problems is about the problem of waste management that occurs in an area. According to data from the Ministry of Environment and Forestry (KLHK), only about 69\% of municipal waste is eventually disposed of to Final Dumpsites (TPA), while the rest are handled individually by communities by being burned or dumped into rivers (Farizal, Aji et al. 2018). Thus, it can be called that the handling of waste based on ordinary people is not in accordance with the application of waste management based on Reduce, Reuse, and Recycle (3R). Because, both handling waste by burning and dumping it into rivers can result in environmental pollution (Wulandari, Utomo et al. 2017).

Meanwhile, a data from the East Java Provincial Environmental Agency (DLH), reported that in 2013 the East Java Province had been experienced by a garbage problem which was caused by $47 \%$ of garbage from settlements; market 19\%; shops, hotels, hospitals, roads and industries, and open land ranges from 3-8\% (Melyanti 2014). From these data, it can be assumed that if it is associated with a source of waste, the problem of waste is primarily due to a large amount of household waste production from residential settlements. Therefore, this can be a consideration for formulating strategic policies or programs in the context of waste management in the region.

One area that has an urgency in waste management, namely Batu City. As a city with the branding of the City of Tourism, Batu City certainly must maintain various aspects that can support tourism activities by creating a clean and healthy city, by organizing appropriate and strategic waste management. So that, waste management in the town of Batu cannot be underestimated, because if managed chaos, it can threaten tourism in Batu City. Moreover, data from the City of Batu DLH shows that Kota Batu produces a high volume of waste every day, with details as follows.

Please cite this article as : Sulung Satrio I.P et al., Application of Co-Production In Waste Management Through Waste Banks Program In Batu City : Journal of Local Government Issues (LOGOS), 
Table 1.1 Waste Volume of Batu City

\begin{tabular}{|c|c|c|}
\hline \multicolumn{3}{|c|}{ Total of Waste in Batu City } \\
\hline 2016 & 2017 & Holiday/weekend \\
\hline 70 tons/day & 80 tons/day & 100 tons/day \\
\hline
\end{tabular}

Source: DLH Batu City, 2017

The data above shows that annual waste production in Batu City from 70 tons/day in 2016 to 80 tons/day in 2017 and even to 100 tons/day on holidays or weekends. If this condition is not handled optimally, it can not only threaten tourism in Batu City but also threaten various aspects of people's lives. Because basically, the problem of waste can also result in multiple negative things such as can affect the health of the surrounding community, because for certain types of debris can cause a source of disease; decrease the beauty or aesthetic value of the city, where bad waste handling; causing air pollution and a foul odor; garbage can cause flood hazards in the rainy season, where un-transported waste can become clogs of waterways (Murdiningsih 2015). In other words, the presence of garbage in Batu City can provide a variety of negative impacts starting from public health problems, reducing the beauty of the city so that it becomes a threat to Batu's tourist attraction, causing air pollution and foul odors, and can cause flooding.

The issue of solid waste in Batu City does not only concern the high volume of debris, but also concerns the lack of policy of program by the City of Batu in conducting waste management, especially in the aspect of providing solid waste facilities. Batu City only has three Integrated Waste Disposal Sites (TPST) in the village and village office, namely in Pandanrejo Village, Dadaprejo Village, and Temas Village from all 24 villages and villages (DLH Kota Batu, 2017). Another problem also arises from the accumulation of garbage in the Final Disposal Site (TPA) due to the amount of waste that exceeds the landfill capacity and the lack of the number of garbage collection machines.

Solid Waste Management in a city does not only depend on waste management at the TPA or TPST. The existence of robust waste policies through Law No. 18 of 2018 about Waste Management is a new paradigm of solid waste management in Indonesia. This policy does not only emphasizes the reduction and waste handling aspects but also can be a new strategy in solving waste problems because it contains the spirit of developing and strengthening public awareness to be involved in waste management through the waste bank model (Wulandari, Utomo et al. 2017).

Referring to those problems, the Batu City Government, through the DLH, must also have a waste management program that does not only emphasize waste management activities in several temporary disposal sites (TPS), sweeping and road cleaning, and waste management in the landfill. However, other aspects must also be taken into account, such as by allowing the involvement of the community through waste banks. This can be a choice for robust waste policies in Batu, considering that there are more than 60 waste banks that

Please cite this article as : Sulung Satrio I.P et al., Application of Co-Production In Waste Management Through Waste Banks Program In Batu City : Journal of Local Government Issues (LOGOS), 
actively carry out waste management activities at the RW level (DLH) Kota Batu, 2017). Many of these garbage banks have been established, which have been followed up by the City of Batu DLH by issuing a Decree (SK) of the Head of DLH No 180/16 / KEP.DLH / 422.110 / 2017 regarding "The Formation of The Batu Bank Waste Community Management." The Batu City Waste Bank (KBS) community, named KBS Kartini Sejati, acts as a coordinator for all garbage bank groups in Batu City and is expected to be able to play a role in coordinating garbage bank groups internally and becoming bridges or connectors between waste bank groups with the government.

Direct community participation through waste bank activities is one of the choices of policies or programs that can be carried out by the government to involve or involve the community deeply in waste management in an area (Asteria and Heruman 2016) (Bachtiar 2015). Furthermore, one concept that can be applied in community-based waste management is by using the idea of co-production (Safitri 2015). Coproduction itself is a concept that is applied to improve the quality of public services by involving the community. This concept is expected to be used in the context of waste management through a waste bank because waste bank activities are also classified as public services in the waste sector.

This study aims to describe the application of the co-production concept in the implementation of the waste bank program in Kota Batu, where the City of Batu DLH collaborated with the Waste Bank in the process of managing domestic waste that was not touched by the DLH waste management system program in Batu City. Also, this study will examine the obstacles that occur in the implementation of the waste bank program in Kota Batu to be a consideration for the implementation of the waste bank program in the next Batu City.

\section{LITERATURE REVIEW}

\section{Co-Production}

The concept of co-production emerged as an effort to improve the quality of public services for the community. This concept also becomes a new paradigm for the provision of public services. Because the public service actors are no longer the government and private parties on their own, but also involve the community. A co-production approach assumes that public services enjoyed by citizens will be better in quality when citizens, especially those gathered in the organization have citizens, participate in the process of providing public services (Putra 2012). Furthermore, Governance International states that the idea of co-production is the effort to provide public services by involving the community, not only for the community but by using community power (Safitri 2015). The need for the district to be involved is caused by the limited capacity of the institutions owned by mainstream public service providers, namely the government and the private sector, which sometimes do not reach the needs of the community.

Please cite this article as : Sulung Satrio I.P et al., Application of Co-Production In Waste Management Through Waste Banks Program In Batu City : Journal of Local Government Issues (LOGOS), 
On the other side, a more comprehensive opinion on the definition of co-production, put forward by Joshi and Moore in (Putra 2012) which states that co-production is the provision of public services (including regulation) through a regular and long-term relationship between organizations in the sphere of government and organized community groups where both parties contribute important resources. Because, through co-production, the community or citizens can play an active role in producing goods and public services that have consequences for them (Ostrom 1996). In other words, the implementation of co-production is not only realized in the technical implementation of the provision of public services, but also in the process where the community makes rules, regulations, or even policies that become the legal basis for implementing co-production-based services.

Furthermore, other vital aspects should be understood in the concept of co-production is the distinction with several different ideas in providing public services, namely co-governance and comanagement. Co-governance is a concept that refers to an order in which the third sector participates in the context of public service planning, while co-management refers to the order in which third sector organizations produce public services in collaboration with government or state (Putra 2012). While co-production emphasizes the dominant role of society or community organizations in creating facilities for themselves.

States that three advantages can be obtained if the provision of co-production based public services are applied (Needham 2008). First, staff who work as the frontline for public services can contribute by understanding more about what consumers want, because they are accustomed to interacting directly with consumers or society. Second, co-production can change people's attitudes to improve service quality because co-production creates users who are involved and more responsible. Third, co-production can realize budget efficiency, with more focus on the output that will be obtained by consumers.

Governance International divides co-production into four types, namely; co-commission, codesign, co-deliver, and co-assess (Safitri 2015). Co-commissioning involves the public sector and the community to work together, using their knowledge and expertise, to prioritize which services should be provided and to whom they should be submitted using public resources and resources from the community. Co-designing refers to a structured approach which seeks to utilize the best ideas of the people who will ultimately use the services and provide these services. This type can be understood that the community is involved and formulates its concept or model of public service that will be applied. Co-delivery refers to cooperation between cities and professional workers to create better public services through creative, innovative, and collaborative ways. This type is more on the aspect of technical implementation where the community as the technical implementer of the provision of

Please cite this article as : Sulung Satrio I.P et al., Application of Co-Production In Waste Management Through Waste Banks Program In Batu City : Journal of Local Government Issues (LOGOS), 
public services. While the Co-assessment involves the city to work hand in hand with professionals to assist the organization in providing a deeper understanding of what they feel from the services offered, in this case, the implementation of co-assessment can be carried out effectively by using electronic media such as social media or websites in the consumer complaints process.

In its application, co-production has principles that become a reference in the provision of public services based on participation or community involvement. New of Economic Foundation (NEF) in (Safitri 2015). Outlines six principles in implementing co-production, which include:

1) Building on people existing capabilities

This principle seeks to change the approach to public service from a passive approach to a plan that provides opportunities for the community to be able to hone and develop the capacity of the city and actively support to place them and be used at the individual and community level.

2) Reciprocity and mutuality

Offer people with a variety of incentives to be involved, which allows us to obtain and obtain good relations with professionals and others, where both parties are mutually responsible.

3) Peer support networks

Involve groups and systems to work with professionals as a means of transferring knowledge or knowledge

4) Blurring distinctions

Remove differences between professionals and recipients, and between producers and consumers in the context of service, by reconfiguring the way services are developed and delivered.

5) Facilitating rather than delivering

Making government institutions possible as catalysts and facilitators rather than acting predominantly as service providers.

6) Assets

Changing the perception of the community from the recipient of passive services and being a burden on the system is one of the equal partners in designing and delivering services.

\section{Waste Management}

Before entering into the discussion on waste management, it needs to be understood first regarding the definition of waste. Tresna in Saputri, et al. (2015:1805) defines waste as the remnants of material that is subjected to treatments either because the central part has been taken or because of management or because there are no benefits that are viewed from a social, economic perspective, there is no price, and in terms of the environment causing pollution or threats to environmental

Please cite this article as : Sulung Satrio I.P et al., Application of Co-Production In Waste Management Through Waste Banks Program In Batu City : Journal of Local Government Issues (LOGOS), 
sustainability. A material that has no value or is not valuable for everyday or extraordinary use and production. Both of these definitions have the same point that in detail, waste is unwanted goods that no longer have social and economic use value anymore. Waste can even provide pollution and is a threat to environmental sustainability. However, there are now several rubbish that still has economic and social use-values thanks to the recycling process. Waste can even be formed into a particular craft that has commercial value. Debris can also be used again for the production process of an item.

Furthermore, in the context of its sources, The tauses of waste based on the location of the origin of the trash are classified into four types of debris, which include domestic waste, commercial waste, industrial waste, and Asamoah natural and others Gumbira in (Safitri 2015). Household waste is a sort of waste originating from housing or residential areas. Commercial waste comes from economic activities such as shops, stalls, restaurants and markets. Industrial waste comes from industrial activities. Natural and other debris can be in the form of leaves or rubbish from natural disasters as well as waste originating from recreational places, terminals, public vehicles, ports, and others.

In solid waste handling, proper waste management is needed. Today, the term integrated waste management system is known as a combination of waste management systems by recycling, composting, combustion (incinerator), and final disposal systems utilizing sanitary landfills (Sucipto 2012). This system is called or also known as the $3 \mathbf{R}$ waste management system name or waste management system which consists of a process of reduce, reuse, and recycle or 3R (reduce, reuse, and recycle).

Integrated waste management by relying on the $3 \mathrm{R}$ concept is also waste management that is following what is contained in Law No. 18 of 2008 concerning Waste Management. The process of waste management with the $3 \mathrm{R}$ idea can be seen through the following chart:

Figure 1 Chart of Waste Management System

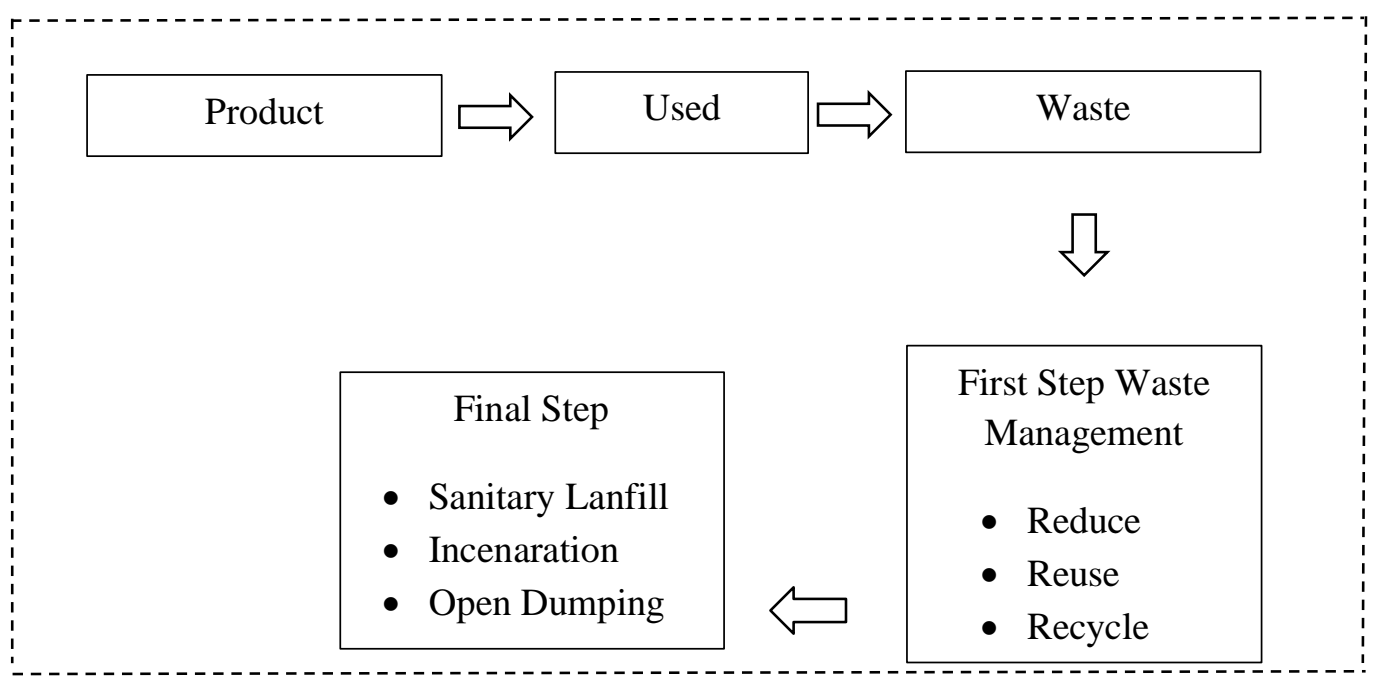

Sumber: Cunningham in Hadhan, 2015

Please cite this article as : Sulung Satrio I.P et al., Application of Co-Production In Waste Management Through Waste Banks Program In Batu City : Journal of Local Government Issues (LOGOS), 
Based on the chart above, modern waste management consists of a 3R process (Reduce, Reuse, and Recycle) before it is finally destroyed or destroyed. 3R waste management is the concept of handling waste by reducing. The reduce principle is to reduce the goods or materials used. Reuse, the law of reuse is to reuse items that can still be used. Recycle, the policy of recycling is to recycle items that can be recycled. When waste is in a landfill (TPA), waste is treated with a sanitary landfill or incinerator, the result of burning trash in the form of ash can be used as raw material for brick and compost mixture. The results of recycling compost can be sold to consumers and the recycling industry. The development of a complete integrated waste management system requires considerable investment capital and effective and efficient operational management.

\section{Waste Bank}

The waste bank is an effort that can be made to contribute to waste management in an area. This waste bank is in the control of a bank, but the banks that are saved are money, whereas, in the bank, the garbage in the tube is garbage. Sampath, which is collected, is usually a type of domestic waste or dry household waste. According to Minister of Environment Regulation No. 13 of 2012 concerning Guidelines for Implementing Reduce, Reuse, and Recycle Through Waste Banks, Waste Bank is a place for sorting and collecting waste that can be recycled and used which has economic value. The Waste Bank can be useful as a place where garbage can be recycled and reused so that it has commercial value that benefits the community.

Waste banks can become economic institutions where waste can be a transaction tool used in their activities, because unlike conventional banks that use money as the main instrument, the waste bank emphasizes its focus on waste management, which is the current environmental problem (Shentika 2016). Changes made by the waste bank system are not entirely due to economic factors, but to increase environmental awareness of the community and aspects of community empowerment (Bachtiar 2015). Thus waste banks not only have an impact on economic development solely for the city but also contribute to social construction because it can raise public awareness of the love for preserving the environment. Furthermore, community empowerment through waste banks can be a capacity building or capacity building effort that is very appropriate for the community.

\section{METHODS}

This research uses a qualitative approach, particularly descriptive type. So, this type of research is descriptive qualitative. Thus researcher conducted the process of collecting data through interviews with the informants based on purposive sampling, the determination of the person interviewed was done purposively, which was chosen with specific considerations and objectives (Sugiyono 2011). Therefore, the informants in this study included the Head of Sie Pembampahaan DLH Batu City and the management of the KBS Kartini

Please cite this article as : Sulung Satrio I.P et al., Application of Co-Production In Waste Management Through Waste Banks Program In Batu City : Journal of Local Government Issues (LOGOS), 
Sejati Kota Batu. This study uses primary data from the interview process with informants. The interview is about the application of co-production elements in the implementation of waste bank programs in Batu City that handle by the central waste bank community, named Komunitas Bank Sampah (KBS) Kartini Sejati. Because KBS Kartini Sejati has many activities in the context of waste management to support government job in controlling waste production in Batu City. The secondary data uses several documents, both from DLH Kota Batu and reports from KBS Kartini Sejati. The data analysis techniques used are technical interactive data analysis from Miles a Huberman which includes data collection, data reduction, data review, and conclusion (Silalahi 2006).

\section{RESULTS AND DISCUSSION}

1. Application of the Co-Production Concept in Waste Management through the Waste Banks Program in Batu City

The waste banks program in Batu City is an attempt by the Batu City Government through the City of Batu DLH to transform the mandate of the Republic of Indonesia Minister of Environment Regulation No. 13 of 2012 concerning Guidelines for Implementing Reduce, Reuse and Recycle through Waste Banks. Therefore DLH Kota Batu in 2014 began pioneering the development of the establishment of several garbage banks in Batu City. At the beginning of the pilot, the number of garbage banks was still very minimal, and only around 14 garbage bank groups. These groups subsequently developed until, in 2017, there were around 60 garbage bank groups spread in Batu City.

In terms of policy or regulation in the area, the garbage bank program in Kota Batu is legally supported by the issuance of the Head of the City DLH Decree No. 180/16 / KEP.DLH / 422.110 / 2017 regarding the establishment of the Batu Bank Waste Community Management. The garbage bank community was formed as a coordinator for all garbage bank groups in Batu City and is expected to be able to play a role in coordinating the garbage bank groups internally and becoming a bridge or connector between the waste bank group and the government. In the process, of course, DLH cannot accommodate and facilitate 60 garbage banks as a whole, so it requires a city-level garbage bank container through KBS Kartini Sejati.

In its involvement in waste management in Batu City, KBS Kartini Sejati is not only tasked with accommodating and facilitating the interests of waste banks but also carrying out several waste management activities that are routinely carried out both once a week and every two weeks. These activities include waste management training activities; waste management activities and sweep activities, clean, nymphing kali (Saber Pungli). The three main activities of KBS Kartini Sejati are those that apply the concept of co-production because, in practice, the community becomes the dominant stakeholder in these activities, compared to the DLH of Batu City, which is only a facilitator. This explanation can be detailed in the following table:

Please cite this article as : Sulung Satrio I.P et al., Application of Co-Production In Waste Management Through Waste Banks Program In Batu City : Journal of Local Government Issues (LOGOS), 
Table 2 Matrix of Activities in the Waste Bank Bank Program in Batu City

Based on Co-Production Principles

\begin{tabular}{|c|c|c|c|c|}
\hline \multirow[t]{2}{*}{ No } & \multirow[t]{2}{*}{ Principles of Co-Production } & \multicolumn{3}{|c|}{ Waste Banks Activities } \\
\hline & & $\begin{array}{c}\text { Waste } \\
\text { Management } \\
\text { Training }\end{array}$ & $\begin{array}{c}\text { Waste } \\
\text { Management }\end{array}$ & Saberpungli \\
\hline 1. & Community capacity building & $\sqrt{ }$ & $\sqrt{ }$ & $\sqrt{ }$ \\
\hline 2. & $\begin{array}{c}\text { The mutual relationship among } \\
\text { stakeholders }\end{array}$ & $\sqrt{ }$ & $\sqrt{ }$ & $\sqrt{ }$ \\
\hline 3. & Networks development & $\sqrt{ }$ & $\sqrt{ }$ & $\sqrt{ }$ \\
\hline 4. & $\begin{array}{c}\text { Horizontal relation among } \\
\text { stakeholders }\end{array}$ & $\sqrt{ }$ & $\sqrt{ }$ & $\sqrt{ }$ \\
\hline 5. & $\begin{array}{l}\text { Government as catalyst and } \\
\text { facilitator }\end{array}$ & $\sqrt{ }$ & $\sqrt{ }$ & $\sqrt{ }$ \\
\hline 6. & $\begin{array}{l}\text { Community as an essential } \\
\text { asset during the delivery } \\
\text { services }\end{array}$ & $\sqrt{ }$ & $\sqrt{ }$ & $\sqrt{ }$ \\
\hline
\end{tabular}

Source: Processed data, 2019

Based on the table above, it can be said that the three activities in the waste bank program in Batu City have demonstrated and applied the co-production principle with the following details.

\section{a. Waste Management Training Activities}

In terms of waste management training activities, activities that generally contain training on recycling waste into handicrafts and compost are carried out by KBS Kartini Sejati to its members, which consist of several waste banks in Batu City. Not only for waste bank members, but training is also conducted for employees at Tlekung TPA. This training activity was carried out by KBS to 20 female employee employees at Tlekung TPA. Training activities are held every Friday morning each week. Although sometimes if there is an obstacle so that training activities cannot be carried out, the True Kartini Bank Waste Community seeks to carry out these activities routinely. The training activities are only limited to plastic waste cycle training to be converted into handicraft products that can have economic value.

The waste training activity shows that with this activity, the waste bank members can have the ability and knowledge in the field of recycling waste into crafts and compost. This is important, as one

Please cite this article as : Sulung Satrio I.P et al., Application of Co-Production In Waste Management Through Waste

Banks Program In Batu City : Journal of Local Government Issues (LOGOS), 
of the efforts to implement integrated waste management based on reducing, reuse, and recycle (3R). This activity also helps and increasingly supports DLH Kota Batu in the effort to develop and empower members of the waste bank, where DLH Kota Batu has possessed waste bank training activities but is Top-Down and only involves waste banks as participants whereas the waste bank training activities held by KBS internally are carried out independently where DLH is only limited as a catalyst and facilitator.

The waste bank training activities which also involve Tlekung TPA employees are evidence that this activity seeks to develop a waste management network that does not only depend on programs from the Batu City DLH. Because, with a number of waste bank administrators who have the capability and knowledge related to waste recycling, DLH Kota Batu considers that this is a valuable asset or capital for training members of the waste bank who do not have the ability to recycle waste.

\section{b. Waste Management Activities}

Waste management activities are the main activity in the waste bank program in Batu City. This activity is related to waste management training activities. However, the difference is that if the training activities place more emphasis on the capacity-building aspect of the waste bank members, waste management activities are a form of exercise that is technically carried out in the efforts of integrated waste management or $3 \mathbf{R}$ in Batu City. Furthermore, this activity has a narrower scope, because it is only limited to the management of domestic waste, especially the misuse of residential settlements. However, this activity still has a high contribution to waste management in both TPST and Tlekung Landfill.

\section{Figure 2 Process of Waste Management Activities of KBS Kartini Sejati}

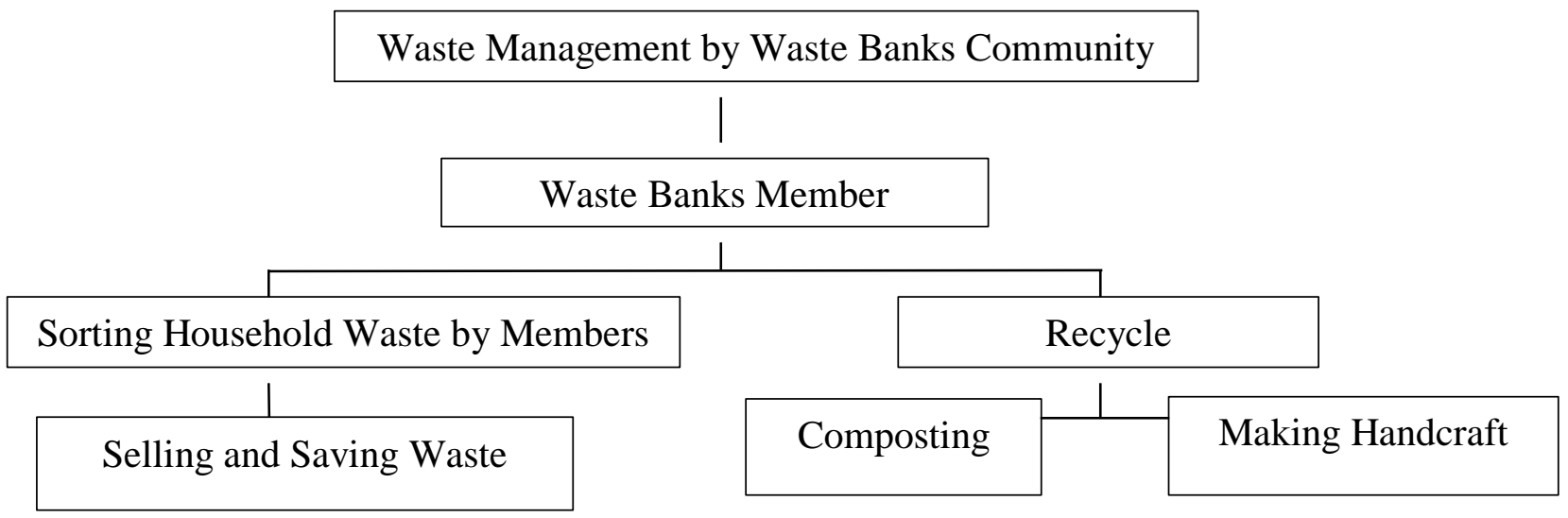

Source: Processed data

Figure 2 shows the process of waste management activities implements by KBS Kartini Sejati Kota Batu. There are two types of waste management activities that are carried out, namely the sorting of household waste by members of the waste bank, which is then carried out by the process of selling and 
saving waste that is deposited to each waste bank every once a month. In the waste collection activity, KBS Kartini Sejati is working with the eLHa Waste Bank as a waste collector owned by DLH Kota Batu. Thus KBS Kartini Sejati, in the process of waste management activities, has the role of coordinating the saving of garbage from each waste bank spread in RW and Kelurahan / Village in Batu City to then be deposited to the Waste Bank eLHa.

Meanwhile, other waste management activities are in the form of recycling activities which include recycling waste into handicrafts and compost. Each waste bank usually does the recycling of garbage into crafts every week, but the level of routine inter-bank activities also varies depending on the operation of the waste bank. The business of making crafts from plastic and paper waste is becoming more routine and even every day. It happened when there are certain events, both events from the Government of Batu City or the Provincial Government.

In terms of compost recycling activities, in reality, not all waste banks from 60 waste banks in Batu City can carry out this activity. This is due to limited knowledge/capability and facilities for composter owned by each waste bank. KBS Kartini Sejati explained that there were only four waste banks from 60 waste banks that had composter devices. Thus, the overall waste management activities in Batu City exclusively relies on the sorting and saving activities of garbage and recycling of waste into handicrafts.

Based on the explanation regarding the waste management activities above, it can be seen that the waste management activities carried out by KBS Kartini Sejati have applied several principles from the concept of co-production. This is because these activities are predominantly carried out by waste banks in every RW and kelurahan/village coordinated by KBS Kartini Sejati. While DLH of Batu City only role as a facilitator. This activity can also be a forum for developing community capacity in the context of knowledge and capability in waste management. Because the community has not only been trained but also directly practices waste management. The implication is that people become aware and understand that household waste produced can be sorted and then saved, even though it is not economically significant. However, this is by the context of $3 \mathrm{R}$ waste management. As well as waste recycling, also though only focus on recycling waste into crafts and still not optimal in carrying out composting activities because of the limitations of the composter facilities.

Furthermore, the involvement of 60 waste bank groups throughout Batu City shows that this activity is network development. Because it doesn't just focus on one waste bank. Waste management activities also greatly help the Batu City government, because, with the limited TPST that not every village/village office has it, the waste management activities of the garbage bank will be able to help the Batu City DLH in realizing the healthy and healthy environment of Batu City from garbage threats.

Please cite this article as : Sulung Satrio I.P et al., Application of Co-Production In Waste Management Through Waste Banks Program In Batu City : Journal of Local Government Issues (LOGOS), 


\section{c. Saberpungli activities}

Batu City is an upstream area of the Brantas River. More accurately, the upstream river is located in Sumber Brantas Village, Bumi Aji District, Batu City. From Sumber Brantas Village, it is the spring of the Brantas River, which is the second-longest river on the island of Java. Therefore, Batu City has a big responsibility to preserve and clean up the river from the upstream. This is because one of the big problems is a large amount of rubbish trash along the Brantas River, which flows along Batu City. On the basis of this concern with the initiative of several community activists in Batu City and Batu City Government, especially the DLH of Batu City, including KBS Kartini Sejati and other community members, they held an activity called Sapu Bersih Sampah Nyemplung Kali (Saber Pungli).

This activity is carried out routinely once a week - this an effort to reduce waste and make the Berantas River clean. So Batu City will look more healthy and beautiful. Saber Pungli's activities are very oriented to creating a community that is aware of the importance of river cleanliness so that it does not throw garbage at random on the River. Every town in Batu City can participate in Saber Pungli activities. In addition, a very interesting thing is that this activity is purely a self-community governing activity. Every community volunteered to come and bring the equipment needed to clean up the garbage in the river.

The Saber Pungli activity held based on an initiative from the community and supported by DLH is very capable of building community awareness not to dispose of garbage in the river because it can pollute and reduce the quality of the Brantas River which also functions as irrigation for both agricultural and plantation activities in Batu City. Community awareness that was built was realized from the form of self-supporting activities. So the hope would be an embarrassment for other people who have the habit of throwing garbage in the river not to repeat it.

The saberpung carried out by KBS Kartni Sejati also demonstrated the application of the coproduction concept in waste management in Batu City. This activity was carried out based on community group initiatives, while the Batu City DLH only supported solid waste facilities, namely one dump truck for each event. Saber extortion activities can also provide awareness for the community of Batu City to maintain the cleanliness of the river. This knowledge is fundamental, considering that the river in Batu City has enormous benefits in the context of supporting agricultural activities as a source of irrigation for agricultural land. So, this activity is also beneficial for programs from DLH to realize a clean river. Also, the involvement of several community groups such as the Batu "Relawan Cinta Lingkungan" community and several other communities showed that illegal saber activities had covered aspects of network development, where these activities were not only carried out by garbage banks but also other parties.

Please cite this article as : Sulung Satrio I.P et al., Application of Co-Production In Waste Management Through Waste

Banks Program In Batu City : Journal of Local Government Issues (LOGOS), 
Based on the explanation above, it can be seen that the three activities carried out by KBS Kartini Sejati have applied the concept of co-production. In fact, all three can also be said to have encoded the six co-production principles which include the policy of developing community capacity, the existence of mutually beneficial relations between the government and the community; network development; horizontal roles and relationships; the government as a catalyst and facilitator; and regard the community as an essential asset in carrying out services. However, if it is seen in general from the description of its activities, it can also be identified that the three events in the waste bank program refer to the type of co-production as follows.

Table 3 Type of Co-Production in KBS Kartini Sejati's Activities

\begin{tabular}{|c|c|c|}
\hline No & Nama Kegiatan & Tipe Co-Production \\
\hline 1. & Wate Managemen Training & Co-Delivery \\
\hline 2. & Waste Management & Co-Delivery \\
\hline 3. & Saber Pungli & Co-Delivery \\
\hline
\end{tabular}

Source: Processed data, 2019

Based on the table above, it can be seen that the three activities of KBS Kartini Sejati are codelivery types. This identification can be obtained because all three of these are carried out in the context of community groups that are initiators and move dominantly in the provision of public services, in this case, namely waste management. In other words, the three activities showed that KBS Kartini, as well as a total of 60 waste banks, carried out these activities independently and independently, where the government, namely the City of Batu DLH, was only a catalyst and facilitator to succeed the business.

Meanwhile, the forefront of co-production in Kota Batu is more on aspects of how the community represented by KBS Kartinisi Sejati provides services in the field of waste, especially household waste, whereas the task of robust waste services should be carried out by DLH or the village government through TPST. In other words, the application of co-production in Batu City has different aspects from some previous studies, where the practice of co-production can occur in children's services (Jakobsen and Andersen 2013), tourism village development programs (Sukmayeti and Utami 2018), and e-government programs which involve community participation (Safitri 2015).

Also, the table above can explain that the implementation of co-production in Batu City through the garbage bank program, has a difference, especially with the existence of Saber extortion activities. Some garbage bank programs that involve community participation are more in the context of waste management such as waste recycling and money exchange in the form of money, as is the case with a conventional bank.

Please cite this article as : Sulung Satrio I.P et al., Application of Co-Production In Waste Management Through Waste Banks Program In Batu City : Journal of Local Government Issues (LOGOS), 


\section{Obstacles of KBS Kartini Sejati to Applicate Co-production in Waste Management}

\section{a. Lack of Budget a Facilities Resource to Support Waste Management}

Budget and facility resources are one of the obstacles in implementing co-production in waste management through the waste bank program. In terms of budget, each activity organized by the waste bank is a personal organization budget for each waste bank, because the DLH of Batu City does not specifically allocate budget for the implementation of any waste management activities both in training activities in waste management, waste management, and illegal saber activities. DLH Kota Batu only supports budget allocations for training the administration and management of waste banks and the provision of waste scales facilities, along with other activities that are less appropriate if they have substantive benefits and contributions to waste management through waste banks, such as comparative studies to waste banks in others. In 2017 DLH allocated a budget of around Rp. 150,000,000 and Rp. 400,000,0000 in 2018. However, practically only training in waste banks and providing facilities have substance in the context of waste management. Even for bank waste training activities alone, there is only one person per waste bank, so it is not evenly distributed to each member.

Meanwhile, the waste bank itself in its operations every year tries to budget independently or independently to support the activities of the waste bank. According to KBS Kartini Sejati, each year, the waste bank requires at least a budget of $\mathrm{Rp} 1,000,000 /$ month for waste bank activities. These needs, so far, have been obtained from the results of membership self-help contributions. This budget limitation is also due to the lack of courage of KBS Kartini Sejati to take the risk of utilizing loan funds offered by one of the Regional Owned Enterprises in Batu City, namely Batu Wisata Resource and working with self-help parties to use the Corporate Social Responsibility (CSR) program.

In addition to concerns, limited budgetary resources, other constraints experienced are limited facilities. The facilities in question are related explicitly to composter facilities, which can be used for waste management activities in the form of compost recycling. Because in the meantime, there are only three garbage banks from 60 garbage banks that have a composter, namely waste banks of Dadaprejo Village, Sisir Village, and Giripurno Village.

\section{b. Decreasing of Community Awareness Level to Be Active in Waste Banks}

Another obstacle faced by KBS Kartini Sejati is related to the decrease in public awareness to be active in waste banks. If this happens, the human resource members of the waste bank will also be increasingly confused and can threaten the existence of the waste bank to continue to contribute to waste management in Batu City actively. This reduced public awareness can be seen from the declining number of members of the waste bank, where only about half of the active members of the waste bank. This condition is influenced by several factors, namely the minimum aspect of economic benefits for waste bank members and the lack of support from the Batu City government.

Please cite this article as : Sulung Satrio I.P et al., Application of Co-Production In Waste Management Through Waste Banks Program In Batu City : Journal of Local Government Issues (LOGOS), 
From an economic aspect, the community's awareness of being declining is active in waste bank activities because the economic benefits obtained in waste bank activities are not significant. Waste bank members can reap financial benefits through the exchange and saving of garbage. In this activity, the waste bank members only get Rp. 500,000 - Rp. 1,000,000 per year, which can only be taken once a year, just before the Idul Fitri. This amount is considered very minimal, although it can also help members of the bank to fulfill the needs of the holiday. However, economic waste bank activities still cannot influence or contribute to the economy of the members of the waste bank. Also, other activities such as recycling waste into crafts and composting are less significant economic benefits, because the results of selling handicrafts and compost are not members' rights, but are allocated into their waste bank cash.

While in terms of the lack of support from the Batu City government through the Batu City DLH, it can also be seen from the lack of budgetary assistance as well as the provision of facilities. KBS Kartini Sejati, as the coordinator of 60 waste banks in Batu City, once submitted a proposal in the form of a request that the DLH allocate a budget of IDR 1,000,000 for each waste bank. However, this cannot be accepted because there are still many waste banks that do not have a notary deed so that the law is still not legal. Meanwhile, in terms of supporting facilities to support the facility, it is still minimal, because only three garbage banks have composter equipment facilities. Supposedly, if DLH finds out about the problem, then DLH must take the initiative to allocate a budget to provide facilities for composter equipment in each waste bank evenly. So that each waste bank can do more waste management activities that are not only fixated on the sorting and saving activities of garbage and recycling of waste into handicrafts but also holding composting operations.

\section{c. Lack of Waste Management Innovation}

The waste management activities carried out by KBS Kartini Sejati, along with around 60 waste banks in Batu City, also showed no innovation to carry out new waste management activities. So far, only three forms of waste management activities have been carried out, namely sorting and waste collection activities; recycling waste into crafts, and composting. These activities are mainstream things done by waste banks. KBS Kartini Sejati needs other activities that can attract interest and the enthusiasm of the community to return to being involved in waste bank activities actively. Such businesses must undoubtedly be able to provide more benefits and benefits for members of the waste bank, especially in terms of the economy.

Therefore, KBS Kartini Sejati needs to innovate or renew waste bank management activities, as has been done by Bank Sampa Malang City (BSM). BSM has unique activities in waste management, especially organic waste, namely worm cultivation. The cultivation of worms uses organic waste produced by waste bank members to be used as food for worms. The results of this worm cultivation

Please cite this article as : Sulung Satrio I.P et al., Application of Co-Production In Waste Management Through Waste Banks Program In Batu City : Journal of Local Government Issues (LOGOS), 


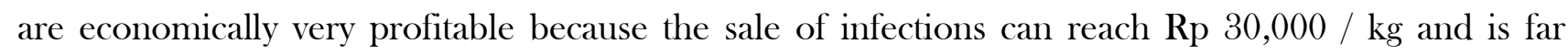
more profitable than just saving garbage, selling handicrafts from recycled waste, and compost.

\section{CONCLUSION}

Waste management in an area must, in practice, involve the community and not only depend on the program run by the local government. This is manifested in waste management in Batu City through a waste bank program. The program itself provides a significant proportion for the community through a waste bank coordinated through KBS Kartini Sejati to be involved in waste management in Batu City. The involvement of KBS Kartini Sejati is significant considering the limited capacity of the waste management system program in Batu City, which does not target households or settlements of residents in villages and villages and does not have TPST by each town in Batu City.

The involvement of the community, through the waste banks, is very much in line with the concept of public service, which today is one alternative to mainstream public services where the government and the private sector are service providers. The idea is co-production, a sense of service delivery that provides the dominant role of the community as a service provider by collaborating with professional parties, in this case, the government/private sector/ other parties.

The application of co-production in the waste bank program in Kota Batu has shown that KBS Kartini Sejati, along with around 60 waste banks, has implemented six co-production principles through three main activities, namely waste management training activities, waste management activities, and Saber Pungli activities. Since the whole of waste bank activities have implemented community capacity building; mutually beneficial relationship between government and society; network development; similarities in horizontal roles and relations; the government as a catalyst and facilitator; and regard the community as an essential asset in carrying out services. Furthermore, the three activities of the waste banks can be categorized as co-delivery types in the concept of co-production. This categorization is because these activities provide technical services in a way that the community plays a dominant role, and the government is limited to facilitating. However, the application of co-production still has several obstacles in its implementation. These constraints include limited budgetary resources and supporting facilities for waste management; decreasing the level of public awareness to be active in waste banks, and the need for innovative waste management carried out by KBS Kartini Sejati.

Based on the problems or problems that arise in the application of co-production in waste management through the waste bank program in Kota Batu, so that in the future it can run optimally, the following efforts are needed.

Please cite this article as : Sulung Satrio I.P et al., Application of Co-Production In Waste Management Through Waste Banks Program In Batu City : Journal of Local Government Issues (LOGOS), 
1. KBS Kartini Sejati must instruct 60 waste banks under their supervision to immediately manage bank legality at the notary so that the government can legally allocate budget funds to each waste bank each month.

2. In terms of policy support, the waste bank program should not only be based on the Decree of the Head of the DLH of Batu City but rather the need for a policy or regulation at the level above through the issuance of the Regulation of the Mayor regarding support for the waste bank. Perwali's presence increasingly shows the political will of the Batu City government to play an optimal role as a facilitator or catalyst for waste management through a waste bank program

3. In the aspect of the need for innovation, KBS Kartini Sejati needs to collaborate by developing a network for Malang City BSM or academics from high education institutions in Malang. Collaboration with higher education institutions can support the development of the capacity of waste bank human resources, especially related to knowledge on waste management, both in composting, implementation of worm cultivation, and the production of methane gas using organic waste from animal waste.

\section{REFERENCES}

Asteria, D. and H. Heruman (2016). "Bank Sampah Sebagai Alternatif Strategi Pengelolaan Sampah Berbasis Masyarakat Di Tasikmalaya (Bank Sampah (Waste Banks) as an Alternative of Community-based Waste Management Strategy in Tasikmalaya)." Jurnal Manusia dan Lingkungan 23(1): 136-141.

Bachtiar, H. (2015). "Pengembangan Bank Sampah sebagai Bentuk Partisipasi Masyarakat dalam Pengelolaan Sampah (studi pada koperasi bank sampah Malang)." Jurnal Administrasi Publik 3(1): 128-133.

Farizal, F., et al. (2018). "Indonesia's Municipal Solid Waste 3R and Waste to Energy Programs." Makara Journal of Technology 21(3): 153-159.

Jakobsen, M. and S. C. Andersen (2013). "Coproduction and Equity in Public Service Delivery." Public Administration Review 73(5): 704-713.

Melyanti, I. M. (2014). "Pola Kemitraan Pemerintah, Civil Society, dan Swasta dalam Program Bank Sampah di Pasar Baru Kota Probolinggo." Jurnal kebijakan dan manajemen publik 2(1).

Murdiningsih, R. (2015). Komisaris Independen \& Independensi Komisaris, Tersedia di http://www. jiwasraya. co. id.

Needham, C. (2008). "Realising The Potential Of Co-Production: Negotiating Improvements in Public Services." Social policy and society 7(2): 221-231.

Please cite this article as : Sulung Satrio I.P et al., Application of Co-Production In Waste Management Through Waste Banks Program In Batu City : Journal of Local Government Issues (LOGOS), 
Ostrom, E. (1996). "Crossing the great divide: coproduction, synergy, and development." World development 24(6): 1073-1087.

Putra, F. (2012). New Public Governance, Malang: UB Press. Retrieved from http://bookstore. ub. ac. $\mathrm{id} / \mathrm{shop} / \mathrm{ilmu}$

Safitri, Y. d. R. N. A. (2015). "Pengembangan Co-Production: Sebagai Upaya Meningkatkan Partisipasi Masyarakat dalam Peningkatan Pelayanan Publik (Best Practice Pada Pelayanan Publik di Kota Bandung)." Jurnal Wacana Kinerja 18.

Shentika, P. A. (2016). "Pengelolaan Bank Sampah di Kota Probolinggo." Jurnal Ekonomi dan Studi Pembangunan 8(1): 92-100.

Silalahi, U. (2006). Metode penelitian sosial, Unpar Press.

Sucipto, C. D. (2012). "Teknologi Pengolahan Daur Ulang Sampah." Yogyakarta: Gosyen Publishing.

Sugiyono (2011). "Metode Penelitian Pendekatan Kualitatif Kuantitatif dan R \& D." Penerbit Alfhabeta Bandung.

Sukmayeti, E. and V. Y. Utami (2018). "Governansi Publik Model Co-Production Oleh Aktor Socio-Preneur (Kasus Desa Setanggor Dan Kawis Krisant)." Jurnal Ilmu Pemerintahan: Kajian Ilmu Pemerintahan dan Politik Daerah 3(2): 120-135.

Wulandari, D., et al. (2017). "Waste Bank: Waste Management Model in Improving Local Economy." International Journal of Energy Economics and Policy 7(3): 36-41.

Please cite this article as : Sulung Satrio I.P et al., Application of Co-Production In Waste Management Through Waste

Banks Program In Batu City : Journal of Local Government Issues (LOGOS), https://doi.org/10.22219/LOGOS.Vol2.No2.149-167 